\title{
The impact of risk on the technological acceptance of mobile payment services
}

\author{
F. Liébana-Cabanillas • F. Muñoz-Leiva • \\ J. Sánchez-Fernández
}

Published online: 20 August 2013

(C) International Network of Business and Management 2013

\begin{abstract}
The aim of this paper is to analyse the users' acceptance of mobile payment on social networks. Although social networks and mobile-related technology are widely accepted by society, mobile payment is not among the most widely used mobile services. In order to analyse the level of acceptance of this technology, as well as the factors that determine its use by the consumers, we have introduced a modification of the classical technological acceptance model, including risk as a variable-given its relevance in the field. The empirical results show a particular support for the effects of external influences, of usefulness and, to a lesser extent, of risk. Our research has several implications for companies, by focusing on consumers' intention of using these services.
\end{abstract}

Keywords Mobile payment - Social media - Technological acceptance model $\cdot$ Intention to use

\section{Introduction}

The fast adoption of mobile technology and virtual social networks (VSN) as key parts of the New Information and Communications Technologies (NICTs) in our society in recent years has had repercussions in terms of profitability, productivity, competitiveness and economic growth, both at the company level and the national

\footnotetext{
F. Liébana-Cabanillas $(\bowtie) \cdot$ F. Muñoz-Leiva · J. Sánchez-Fernández

Marketing and Market Research Department, University of Granada (UGR), Campus Cartuja, 18071 Granada, Spain

e-mail: franlieb@ugr.es

F. Muñoz-Leiva

e-mail: franml@ugr.es

J. Sánchez-Fernández

e-mail: sanchezf@ugr.es
} 
level in some countries (Dehning and Stratopoulos 2003; Lafuente 2005; Cotec Foundation 2011).

According to the Annual Report of the Spanish Telecommunications Market Commission (2012), the Spanish mobile telephone market has 55.9 million mobile telephone lines, compared to 19.3 million landline telephone lines. These data result in 123.7 lines for every 100 inhabitants, while according to the data of the Spanish Household Panel for the year 2009, this ratio stood at 109.7 lines, compared to 59.9 lines in 2000. In percentage terms, there has been an increase of $12.76 \%$ since last year and of $106.51 \%$ since the beginning of the new millennium.

Today, mobile communications are being driven by different factors (Buellingen and Woerter 2004): first of all, the social trends that determine the ways of communication in the private and public sphere, as well as the possibility to personalize services; second, the technology transfer, which enables not only voice transmission but also access to Internet protocols, encouraging market growth, competition and international competition between companies; lastly, the economic factors such as cost reduction and price adjustment, which increase the use of this type of mechanisms.

According to the reports published by Morgan Stanley (2009) and Multi-sector Business Association of Electronic, Information and Communications Technologies, Telecommunications and Digital Content Companies and Accenture (2011), the Mobile Internet market exceeds 800 million users and it is estimated to have a turnover of around $\$ 120$ billion in 2014 .

According to Multi-sector Business Association of Electronic, Information and Communications Technologies, Telecommunications and Digital Content Companies and Accenture (2011), the primary uses of mobile Internet are: sending and receiving electronic mails on/from mobile phones $(74 \%)$, sending and receiving electronic mails through an email provider's website $(72 \%)$, access weather forecasting $(68 \%)$, access online communities $(68 \%)$, route searching (67\% on average), news reading (66\%), instant messaging (64\%), video downloading or viewing $(61 \%)$, location services $(56 \%)$ and downloading of programs and applications $(55 \%)$.

In the same line, Antevenio's study (2010) about mobile navigation trends analyse, practically all Internet users have mobile phones equipped with a highspeed connection, although only $43 \%$ of them have a data transfer fee. Furthermore, $64 \%$ of mobile Internet users are intensive users (daily or weekly access). Regardless of users' profile, email reading is the main use of mobile Internet $(69 \%)$, followed by navigation $(60 \%)$, access to social networks (43\%), and downloading of content $(25 \%)$.

In its last Annual Report on Digital Content in Spain (2011), the National Observatory of the Telecommunications and Information Society (2012) estimates that $41.6 \%$ of the population uses VSNs regularly. This figure reaches $55.6 \%$ if only Internet users are considered. Besides, these figures are higher in the Interactive Advertising Bureau Spain y Elogia (2011) about Social Networks on the Internet, which reveals that $75 \%$ of Internet users are also social network users. According to this report and Sanz-Blas et al. (2013), there has been a $44 \%$ increase during the last 2 years, when the penetration rate has risen from $51 \%$ in 2009 to 
$75 \%$ in 2011, with Facebook reaching a penetration rate of almost $100 \%$ among sample users (aged 18-55).

In Spain's case, according to National Observatory of the Telecommunications and Information Society (2011), $15.2 \%$ of Internet users made some type of purchase on their mobile phone in 2010, slightly more than in 2009. However, there is a significant leap between mobile technology and conventional Internet as a means of purchase, in spite of the advantages offered by mobile commerce compared to e-commerce, such as: ubiquity (it enables virtual transactions anytime and anywhere), localisation (the mobile phone is a means of communication and trading which moves along with the consumer, enabling the adaptation of products and services depending on their location), convenience (the mobile phone maximizes flexibility and adapts to consumers' schedule and needs), and customisation (the mobile phone is generally a tool for personal use, so the individual is the target market) (Antevenio 2010; Glajchen 2011; San Martín Gutiérrez and López Catalán 2012; Gil-Pechuán and Conesa-García 2013).

In this paper, we analyse mobile payments, which according to Weber and Darbellay (2010) and Liébana-Cabanillas (2012) refer to individual or business activities involving an electronic device with connection to a mobile network, which enables the successful completion of an economic transaction. In the present case, we will analyse a mobile payment system which uses the SMS as a confirmation of the transaction completed. Our research is structured around six sections. Following this introduction, we will analyse the existing payment systems establishing the ones that are used more commonly. The 'Technology acceptance model in mobile payment systems: research hypotheses' and 'Methodology' sections explain the hypotheses and the methodology that stand at the basis of our research. In the 'Results' section, we analyse the results obtained and we sum up by reviewing the conclusions, limitations, and implications of the study.

\section{Payment systems in new electronic environments: mobile payment}

The new payment systems are a result of ICT developments in the field of economic transactions between companies and their customers. In particular, they have emerged as a way of solving certain problems related to cash handling (Tamayo 1999), such as: (1) the need to reduce the cost of money and existing payment systems; (2) ensuring flexibility for minor purchases and instant payments; (3) increasing security and protection against fraud and other forms of crime; (4) the appearance of e-commerce on the Internet and online payments.

According to a Report by B2C Electronic Commerce of the National Observatory of the Telecommunications and Information Society (2012), the main payment tool for online purchases in Spain is by credit card (64.6\%), followed far behind by cash on delivery (COD) payment and bank transfer (13.6 and $9.2 \%$, respectively); however, new payment options have appeared and gained ground in recent years, such as prepaid cards, PayPal and even mobile payment. Although these systems are not very widespread at the moment, they will become important rivals to traditional payment systems. 
Mobile payment is considered by many experts as one of the applications with the greatest potential in this sector, as the future "star" or "killer" application in mobile communications (Hu et al. 2008). Accordingly, mobile payment can be defined as any type of individual or business activity involving an electronic device with connection to a mobile network enabling the successful completion of an economic transaction (Liébana-Cabanillas 2012). Therefore, it consists mainly in the completion of payments and transactions between two parties, in a fast, convenient, safe and simple manner, at any time and from any place through a mobile terminal. This payment system presents several advantages for companies and users when compared to alternative payment systems in e-commerce (point of sale). Significant advantages for companies and vendors include (among others): increased versatility, considering the large number of existing mobile phones, faster transactions, greater convenience, time-saving, and lower costs (lower discount rates), etc. On the other hand, users experience safer interactions for economic transactions thanks to GSM, UMTS technologies and SIM cards, which permit better encryption of transaction data, thus improving reliability and reducing wait times and errors (San Martín Gutiérrez and López Catalán 2010), among others.

Mobile payments can be classified according to three main criteria: the type of service, the technology used and the purpose (Innopay 2009). Regarding the type of service, the most usual ones are mobile ticketing for shows, mobile parking, mobile remittances and mobile payment at the point of sale.

Depending on the different payment technologies used on mobile phones, different payment systems can appear, particularly payment by short message service (SMS), payments through Wireless Application Protocol applications (WAP), contactless payments (NFC-Near Field Communication), Unstructured Supplementary Service Data based payments (USSD) and also payment through the voice recognition technology.

Finally, it is also possible to classify the tools depending on the purpose. Therefore, m-payment refers to the completion of payment for a given purchase; the m-order manages mobile purchase orders; m-banking refers to the access to electronic banking on the mobile phone; $m$-delivery or delivery on the mobile phone of the purchased services; and m-contract or mobile hiring of services.

Our research study is focused on a payment system which uses sms as a technology to complete the payment.

\section{Technology acceptance model in mobile payment systems: research hypotheses}

Several models have been used so far to measure technology acceptance. In this study, we will use Davis et al.'s (1989) TAM, as it is the most commonly used model in the scientific literature (Wei et al. 2011) concerning the adoption of mobile business services (see Fig. 1), as well as some modifications due to the environment in which the research is conducted.

This model has been used in many fields to predict the acceptance and use of new technologies such as the Internet (Moon and Kim 2001), the electronic commerce (Gefen and Straub 2000), the mobile Internet (Cheong and Park 2005), the use of 


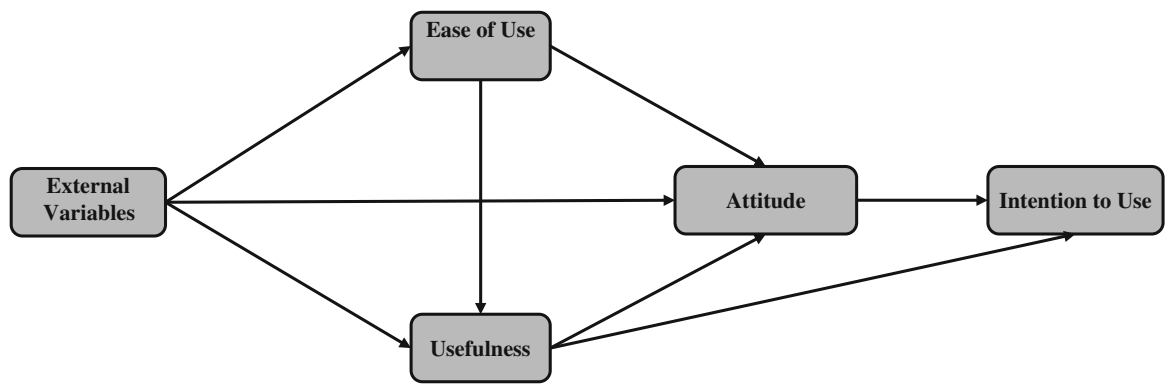

Fig. 1 Technology acceptance model (Davis et al. 1989)

online services (Chau and Lai 2003), the mobile services (Troshani and Rao 2008), the online payments (He and Mykytyn 2007), the mobile banking (Chung and Kwon 2009), the 3G services (Kuo and Yen 2009), the mobile payments (Swilley 2010) among others.

The main modification we have introduced in the TAM is the integration of the 'perceived risk' variable. Many authors establish different dimensions for risk perception (Herrero 2005; Muñoz 2008; Luo et al. 2010) in the environments of electronic payment systems: performance risk or functional risk, financial risk, temporary risk, psychological risk, social risk, privacy risk and general risk. However, for this research, we have used a one-dimensional scale to measure this construct, derived from the adaptations made by Muñoz (2008) to Wakefield and Whitten scale (2006), initially Jarvenpaa et al. scale (2000), although adapted to our particular case. Besides, we have included a second-order construct that we called 'external influences', based on the classic variables of 'social image' and 'subjective norms' as antecedents of the ease of use, attitude and intention.

\section{External influences}

According to the scientific literature, social image and subjective norms are the two classic variables used in TAMs and its later adaptations (Venkatesh and Bala 2008). Specifically, Goffman (1967) defines social image as a 'desired social value that each person creates through interaction with others'. On the other hand, subjective norms are defined as 'the degree with which an individual perceives that people who are important to them think they should or shouldn't use a certain system or perform a certain action, etc' (Venkatesh and Bala 2008).

In our research, on the acceptance of a new mobile payment system (appearing in virtual social networks, VSN), users may experience a feeling of uncertainty regarding the consequences of use and, therefore, may opt for the possibility of consulting opinions and experiences from other users through social networks, adding social image to subjective norms, and leading to a new second-order factor (Del Barrio and Luque 2012). Lu et al. (2005) discuss the relationship of TAMrelated studies and incorporating this approach into their models, with certain empirical support (e.g. Agarwal and Karahanna 2000; Venkatesh et al. 2003), and therefore consider social influences equivalent to subjective norms in the TRA, 
formulating this factor based on other people's opinions and environmental influences.

Therefore, in our VSN environment, there is a conceptual relationship between social image and subjective norms - on the one hand, as a desired social value, and on the other hand, as an influence of the social environment of those who use the new payment system. In our case, we have decided to implement a second-order factor, covering both variables (influence and social image/subjective norms), which we will call 'external influences'. For this reason, we propose the following research questions:

RQ1 External influences have a positive effect on the ease of use the new mobile payment system.

RQ2 External influences have a positive effect on the perceived usefulness of the new mobile payment system.

Apart from the classic relationships, we have detected the theoretical existence of a relationship between social image and intention (Venkatesh et al. 2003; Shin 2007; Lu et al. 2008) and between subjective norms and intention (Venkatesh and Bala 2008; Glass and Li 2010), which is why we propose the following research hypothesis:

H1 External influences have a positive effect on the intention to use the new mobile payment system.

Ease of use of the new mobile payment system

The ease of use is an individual's perception that using a certain system will be free of effort or simply easy to accomplish (Davis 1989; Taylor and Todd 1995). Sánchez Franco et al. (2007) and Fadil (2009), among others, confirm that the ease of use perceived by the user has a positive impact on the usefulness and attitude shown by the user. On the basis of this approach, we propose the following hypotheses:

H2 The ease of use of the proposed mobile payment system has a positive effect on users' attitude towards it.

H3 The ease of use of the proposed mobile payment system has a positive effect on its perceived usefulness.

Usefulness of the new mobile payment system

The TAM also proposes that perceived usefulness is a fundamental precedent of users' attitude towards the intention of use (Davis 1989). Various researches have demonstrated how usefulness is directly related to attitude, as well as the intention of use. Along these lines, there is significant research on the use of social networks (Hossain and de Silva 2009), Travel 2.0 tools (Muñoz-Leiva et al. 2012), mobile Internet (Cheong and Park 2005) and mobile services (Kargin and Basoglu 2006), among others. We therefore propose the following hypotheses: 
H4 Perceived usefulness has a positive effect on users' attitude towards the proposed mobile payment system.

H5 Perceived usefulness has a positive effect on the intention to use of the proposed mobile payment system.

Attitude towards the new mobile payment system

On a different note, the relationship between attitude towards technological innovation and the intention of use has been empirically supported by research in different fields of study, such as using an information system (Bhattacherjee and Premkumar 2004), the intention of online auctions (Huang et al. 2011) and mobile payment systems (Schierz et al. 2010), etc. We therefore propose the following hypothesis:

H6 Users' attitude towards using the proposed mobile payment system has a positive effect on their intention to use it.

Perceived risk of the new mobile payment system

Finally, as mentioned previously, different research studies have revealed that the perceived risk has a negative influence on attitude (Teo and Liu 2007; Hsu et al. 2011) and, of course, on the intention to use (Lorenzo Romero et al. 2011; Kesharwani and Bisht 2012; Lee and Song 2013). Miyazaki and Fernandez (2001) state that the online purchase rate is negatively related to risk perception. Considering these circumstances, we propose the following hypotheses:

H7 The perceived risk of the proposed mobile payment system has a negative effect on users' attitude towards it.

H8 The perceived risk of the proposed mobile payment system has a negative effect on users' intention to use it.

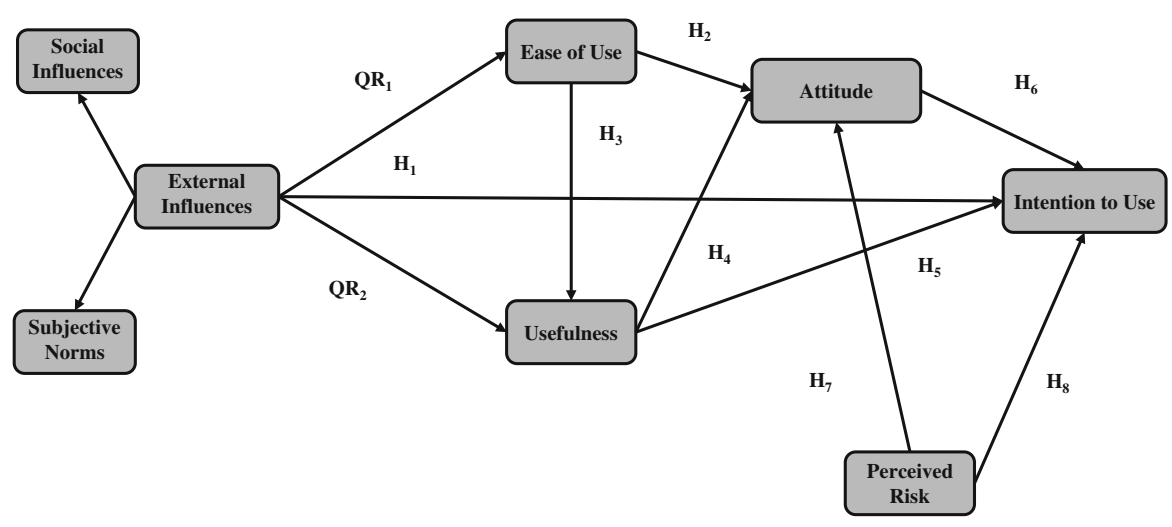

Fig. 2 Proposed model 
The final proposed model is summarized in Fig. 2.

\section{Methodology}

Our research involved a national panel of Internet users with profiles on social networks that navigate through an experimental scenario of a Facebook profile, where they watch a video that explains the proposed new payment system. The payment system is called Zong, which permits the purchase of multiple physical and online content using a mobile device, through a very simple procedure that allows to process payment for purchases in different formats (Internet, social networks, television and even POS). This payment can be diverted to the user's telephone bill or a linked bank card at the time of service activation. Its highest level of activity is among the payment systems on Facebook and online games platforms, as well as on shopping websites. In the present case, we have selected a real web environment adapted to the requisites of our research (external links, access to events, etc. were previously removed), though maintaining the whole appearance of the reference website. To this end, we reprogrammed the Facebook profile concerned and implemented the payment tool in operational condition. The study's technical record is summarized in Table 1.

The size of the final sample was 684 valid questionnaires, using a quota sampling method based on users' characteristics as reflected in the National Statistics Institute (2012).

The questionnaire and the scales used to create it are included in Appendix.

\section{Results}

Reliability and validity of measurement items

To verify the suitability of the measurement scales used, we applied various forms of analysis: reliability, validity, exploratory (using the program SPSS 19.0) and confirmatory (using AMOS 18 software).

Table 1 Technical research record

\footnotetext{
* For the estimate of a proportion where $P=Q=0.5$ and a confidence level of $95 \%$ according to the principles of simple random sampling
}

\begin{tabular}{ll}
\hline Based on the suppositions of a simple random sample \\
\hline Population & $\begin{array}{c}\text { Internet users with a Facebook } \\
\text { profile } \\
14.3 \text { million users }\end{array}$ \\
Population size & By convenience and by quotas \\
Type of sample & Through the company itself \\
Participation incentives & Interviewing through a \\
Type of survey & website \\
Sample size (started & 915 \\
questionnaires) & 684 \\
Valid sample & $3.75 \%$ \\
Sample error* & January and February 2012 \\
Field work period &
\end{tabular}


Table 2 Convergent validity and internal consistency reliability

\begin{tabular}{lllll}
\hline Variable & Items & $\begin{array}{l}\text { Cronbach's } \\
\text { alpha }\end{array}$ & RC & AVE \\
\hline Social image & 3 & 0.98 & 0.98 & 0.94 \\
Subjective norms & 4 & 0.93 & 0.93 & 0.78 \\
Perceived ease of use & 4 & 0.88 & 0.88 & 0.64 \\
Perceived usefulness & 5 & 0.94 & 0.95 & 0.81 \\
Attitude & 4 & 0.95 & 0.95 & 0.84 \\
Perceived risk & 5 & 0.93 & 0.93 & 0.78 \\
Intention to use & 4 & 0.97 & 0.97 & 0.92 \\
\hline
\end{tabular}

First, to measure the scales' reliability, we applied the Cronbach alpha indicator (see Table 2), with 0.6 as the reference value (Malhotra 1997), and 0.7 to be more restrictive (Nunnally 2010). A Confirmatory Factorial Analysis was also conducted to compare the scales' convergent and divergent validity.

The convergent validity was evaluated through the indicators' factorial loads. We verified that the coefficients were significantly far from zero and that the loads between the latent and observed variables were high in all cases $(\alpha>0.7)$. It could therefore be confirmed that the latent variables adequately explained the observed variables (Hair et al. 1995).

In terms of discriminant validity, we confirmed that the variations were significantly far from zero and that the correlation between each pair of scales was not greater than 0.9 (Hair et al. 1995).

The scales' reliability can be evaluated based on a series of indicators extracted from the confirmatory analysis. Specifically, the factor's compound reliability (CR) and extracted variance analysis (EVA) surpassed the reference threshold, 0.7 and 0.5, respectively, as well as other indicators of global adjustment for the corresponding models of individual measurements (Hair et al. 1995).

In regards to asymmetry and kurtosis values of the sample, many present problems in one sense or another, leading to the conclusion that the sample did not follow a normal multivariate distribution (Mardia coefficient $=536.761$; critical ratio, $C R=177.371$ ). Following the recommendations of Hair et al. (1995), considering the absence of normality of the variables, we opted for the maximum likelihood estimation method and bootstrapping technique (or bootstrap learning samples) for 500 consecutive steps or samples, and a significance level of $95 \%$.

Adjusting the model with absolute, incremental, and parsimonious measurements verified that the model's adjustment was reasonably effective $\left(\chi^{2}=1178.961\right.$; $P=0.00 ;$ RMSEA $=0.06 ;$ TLI $=0.96 ; \mathrm{NFI}=0.95 ; \mathrm{CFI}=0.97 ; \mathrm{GFI}=0.88$; $\mathrm{AGFI}=0.87$ ).

Once the quality of all the proposed measurement scales was evaluated, we confirmed that all the latent factors together had sufficient discriminant validity; in other words, the diverse factors formulating the model were significantly different, since the discriminant validity between the dimensions of one scale does not guarantee the discriminant validity that the different latent factors should have. For 
this reason, a Factor Analysis was conducted, including all the measurement scales in order to extract each variation, as well as the correlations between factors and their confidence intervals (Fornell and Larcker 1981; Farrell and Rudd 2009).

In our case, we confirmed that the factors were not very highly correlated (Bagozzi 1994), that no factor had a value of 1 in its confidence interval (Anderson and Gerbing 1988) and that the correlations between the indicators were less than the roots of the variation extracted from each of the factors taken two by two (Fornell and Larcker 1981). These results led us to conclude that there was overall discriminant validity between the different latent factors considered.

\section{Analysis of the obtained structural model}

For the evaluation of the structural model, an analysis of the statistical significance of the model structural loads was carried out. The structural equation modeling (SEM) analysis results, as well as the results of the hypotheses are listed in Table 3.

First of all, research question RQ1 and RQ2, and Hypotheses 1 and 2 could not be rejected $(P<0.001)$, thus proving the importance of the second-order construct we introduced ('external influences') based on subjective norms and social image in the VSN environment. In the present case, it is obtained from an improvement of status derived from the use of the tool in the social network environment and from the influence of the people considered really important for the user and who will normally be part of the list of "friends" in the social network user's profile. That is to say, the people who participate in the social network will have a decisive influence on the way users perceive the ease of use of the new payment system $(\beta=0.415, P<0.001)$ and its usefulness $(\beta=0.690, P<0.001)$, as well as on the intention to use it $(\beta=0.438, P<0.001)$.

Second, the hypotheses derived from the effect of the ease of use (Hypotheses 2, 3 ) could not be rejected either. Thus, the ease of use has a direct and positive impact on attitude $(\beta=0.256, P<0.001)$ due to the lack of relative effort the user needs for using the new tool (Hossain and de Silva 2009), as well as on the usefulness

Table 3 Statistical significance of the standard structural loads

\begin{tabular}{|c|c|c|c|c|c|}
\hline Hypothesis & Effect & Coefficients & SE & Significance & Result \\
\hline RQ1 & $\mathrm{EI} \rightarrow \mathrm{PEOU}$ & 0.415 & 0.047 & 0.000 & Support \\
\hline RQ2 & $\mathrm{EI} \rightarrow \mathrm{PU}$ & 0.690 & 0.057 & 0.000 & Support \\
\hline $\mathrm{H} 1$ & $\mathrm{EI} \rightarrow \mathrm{IU}$ & 0.438 & 0.086 & 0.000 & Support \\
\hline $\mathrm{H} 2$ & $\mathrm{PEOU} \rightarrow \mathrm{ATT}$ & 0.256 & 0.036 & 0.000 & Support \\
\hline H3 & $\mathrm{PEOU} \rightarrow \mathrm{PU}$ & 0.264 & 0.038 & 0.000 & Support \\
\hline $\mathrm{H} 4$ & $\mathrm{PU} \rightarrow \mathrm{ATT}$ & 0.618 & 0.033 & 0.000 & Support \\
\hline H5 & $\mathrm{PU} \rightarrow \mathrm{IU}$ & 0.392 & 0.069 & 0.000 & Support \\
\hline H6 & $\mathrm{ATT} \rightarrow \mathrm{IU}$ & 0.064 & 0.045 & 0.100 & Support \\
\hline H7 & $\mathrm{PR} \rightarrow \mathrm{ATT}$ & -0.088 & 0.028 & 0.000 & Support \\
\hline H8 & $\mathrm{PR} \rightarrow \mathrm{IU}$ & -0.074 & 0.03 & 0.003 & Support \\
\hline
\end{tabular}




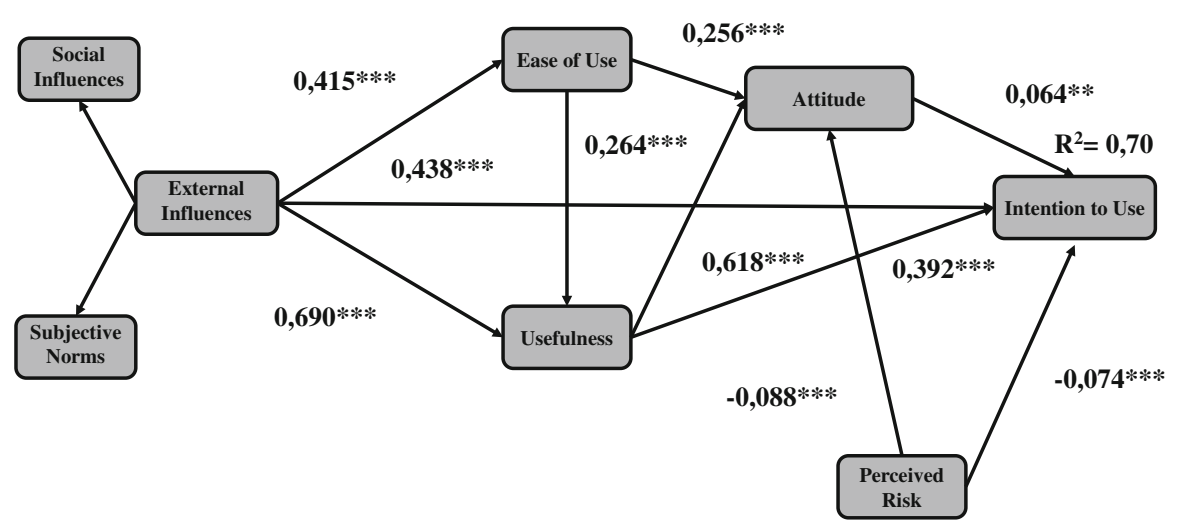

Fig. 3 Results for structural model analysis $* * * 0.01$ of significance, $* * 0.1$ of significance

( $\beta=0.264, P<0.001)$ perceived by users regarding the new mobile payment system (Lorenzo Romero et al. 2011).

Moreover, the relationship between usefulness, attitude and intention in Hypotheses 4 and 5 could not be rejected either. This time, the usefulness perceived by users regarding the payment tool will have a direct impact on their attitude towards it $(\beta=0.618, P<0.001)$ and on their intention to use it in the future $(\beta=0.392, P<0.001)$. These results will entail a direct and positive relationship between the usefulness of the payment tool and the user's attitude and intention towards it (Lorenzo Romero et al. 2011).

On the other hand, Hypothesis 6 relating the favourable attitude towards the payment system and the intention to use cannot be totally rejected either ( $\beta=0.064, P<0.10)$, although it shows a lower value than the rest of variables linked to the intention to use. In the same line with Ajzen and Fishbein (1980) and other following studies, a user's favourable attitude towards a given mobile payment tool will improve his/her intention to use it. Even though it is difficult to define a potential user's attitude due to the multidimensionality of this construct, this relationship has been confirmed in studies related to mobile payment systems (Schierz et al. 2010).

Finally, we cannot reject any of the relationships proposed for the perceived risk: Hypothesis 7, which establishes a negative relationship with attitude $(\beta=-0.088$, $P<0.001)$ and Hypothesis 8 with intention $(\beta=-0.074, P<0.001)$; in the case of our interest, when the payment system is considered risky, user's attitude is reduced just as much as the intention to use, as was proved, in line with the results obtained by other researchers (Gupta et al. 2010; Glover and Benbasat 2011; Zhou 2012) (Fig. 3).

\section{Conclusions, implications and future research lines}

Social networks and mobile phones are among the significant developments in recent years. In this context, we are currently witnessing a trend of integrating these 
two technologies. In Spain, in particular, the use of social networks on mobile phones reaches $68 \%$ of users having a mobile phone with Internet connection (Multi-sector Business Association of Electronic, Information and Communications Technologies, Telecommunications and Digital Content Companies and Accenture 2011). This is precisely why we have analysed the intention towards a new payment system on social networks using the mobile phone as a tool to complete the payment.

Although several research studies about the acceptance of mobile technology have been conducted so far, as well as different methods of mobile payments based on the TAM, this is the first study which proves empirically what are the decisive factors in consumer's acceptance of payments via SMS, introducing also the variable of risk, which — as mentioned previously—is one of the most emphasized by users.

The results obtained in our model prove that all the relationships derived from the proposed research hypotheses are significant and the model as a whole is highly explanatory $(70 \%)$. The variable with the greatest impact on intention was the external influence, formed from social image and subjective norms. This relationship is explained by the online environment where the users perform their activity, since the network itself is the place where communication takes place between people. Therefore, precisely within that network the users will shape their acceptance of the payment tool. Second, the intention to use is influenced by the usefulness of the mobile payment system. This second element consolidates the considerations of the TAM, but departs from the external influence values. In the third place, attitude also has a significant, direct and positive impact on the intention to use. Precisely, these feelings or attitudes users show towards the payment tool also influence to some extent their predisposition to use it. Finally, perceived risk has a negative effect on intention, due to the new user's uncertainty towards the tool and/or the eventual negative consequences of the purchase as well as to the user's attitude towards the proposed payment system.

One of the most important contributions has been the integration of perceived risk in order to understand, explain and predict consumer acceptance of the mobile payment system. Therefore, from a theoretical perspective, the present model aims to provide a more detailed and comprehensive view of the behavioural intention determinants, by integrating perceived risk into the TAM.

In the light of these results, companies will need to value the role played by social environment in their customers' behaviour, and more exactly in the behaviour derived from social networks. Hence, the need for companies to position themselves not only among their clients, but also among the acquaintances and friends of their clients, in order to encourage sales and payments as much as possible, putting in place fast and efficient payment systems. Likewise, they will need to stimulate positive attitudes towards these payment systems, as well as a proper channelling of their usefulness to improve the intention to use. Finally, they will need to introduce as many safety measures as necessary to reduce the impact of perceived risk on future behaviours.

This document presents a series of limitations that must be debated, and which may lead to future lines of research. In regards to the sample chosen, we have only 
considered a panel of internet users with profiles on Facebook's social network, which could lead to a distortion of the results and problems in extrapolating our conclusions; therefore, we should try to expand the study to a more representative, heterogeneous sample in future research (Twitter, Youtube, etc.). Similarly, sample users participating in the website visits were limited to watch a video and read a text describing the functions of this tool. Based on this viewing, our research has focused on measuring the intention of use, but does not reveal the true behaviour of individuals with the system. Achieving a real interaction with the system requires the use of a mobile device and websites for purchases as part of the system, which would significantly increase the complexity of this study. In regards to the data collection method, this research has been conducted with using a cross-section, which does not allow for the analysis of the evolution of users' behaviour over time. A long-term focus would allow us to verify the robustness of the established relationships and factors and, from a temporary perspective, the evolution of the effects of other analysed moderating variables (gender, age and experience of users).

As immediate research lines, we can suggest in the first place the inclusion of new variables in the proposed model, such as trust or perceived quality; in the second place, the integration of real-use measurements of the proposed tool and the comparison of results for all the possible means for each tool (internet, social networks, TV, etc.), assuming that real-use measurement and the relationship between intention and use or acceptance can be compared, drawing the most relevant conclusions. In the third place, in order to give greater external validity to our results, we have considered conducting a comparative study of different payment systems, establishing user categories and profiles for each one, including other technologies that are being considered substitutes for credit card payments also using mobile technology (mainly Near Field Communication, or NFC). In the fourth place, we should compare the user's intention to use the payment tool according to the product or service they wish to acquire, analysing the degree of implication for each of them. Lastly, considering the problems for the sample selection among national citizens, and with the aim of generalising and comparing the results obtained in our research, it would be interesting to conduct the same study in another country or with citizens of different nationalities (cross-cultural), in order to observe the extent to which our conclusions are consistent with others and to replicate the study on other payment channels that users might choose for their purchases.

Acknowledgments This study is being conducted with the financial support received from Excellence Resarch Project P10-SEJ-6768 of the AndalusiaRegional Government.

\section{Appendix}

See Table 4. 


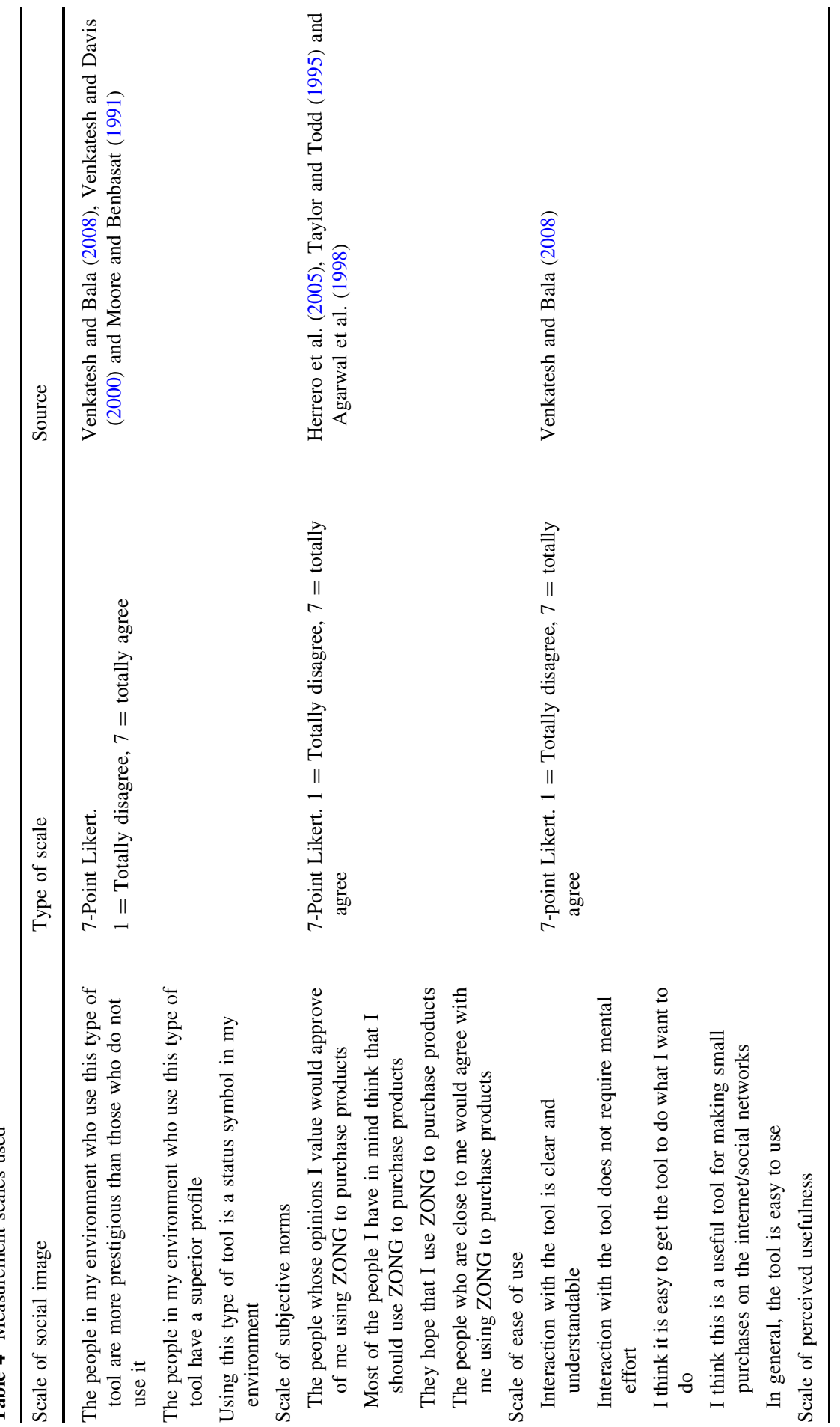




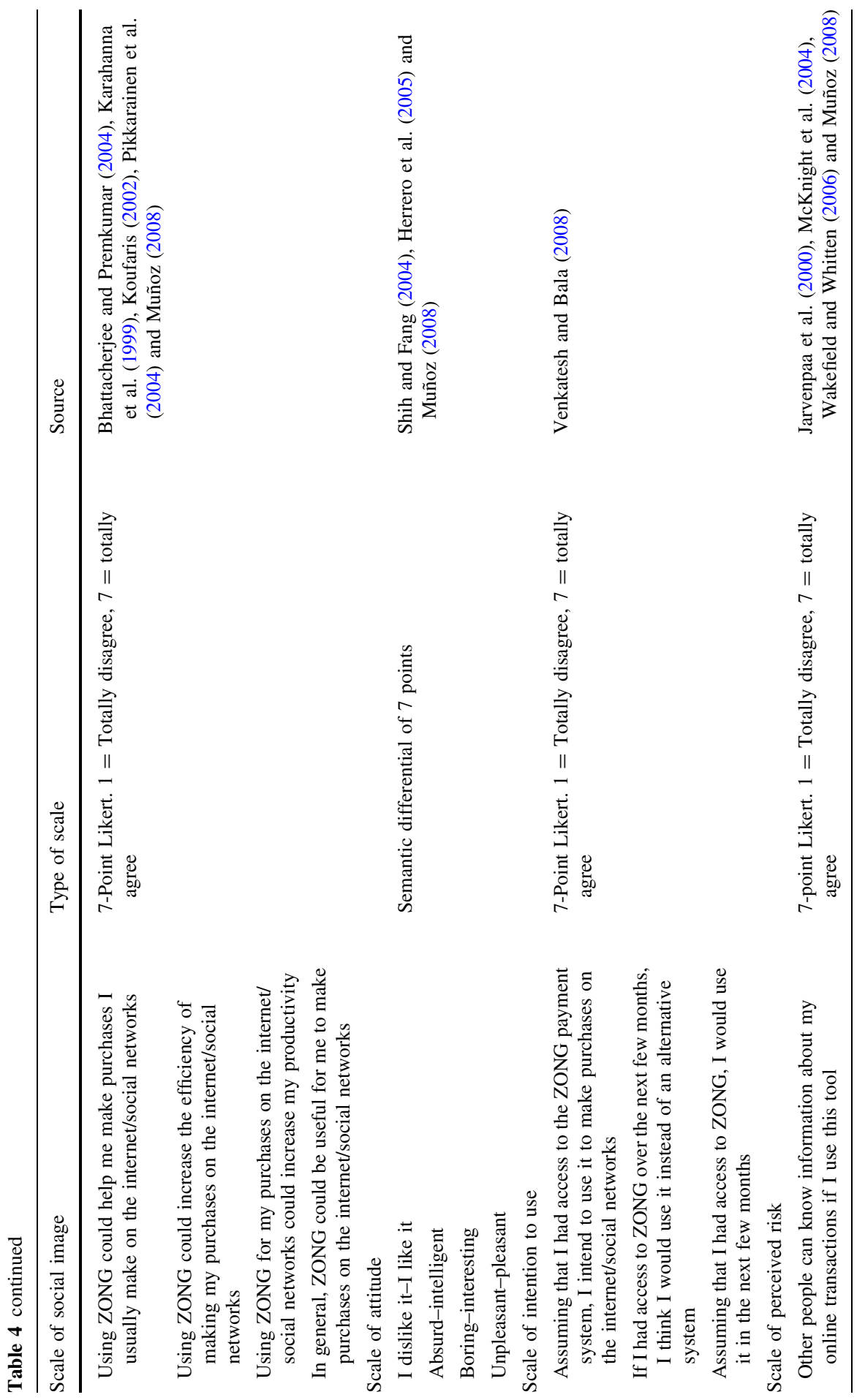




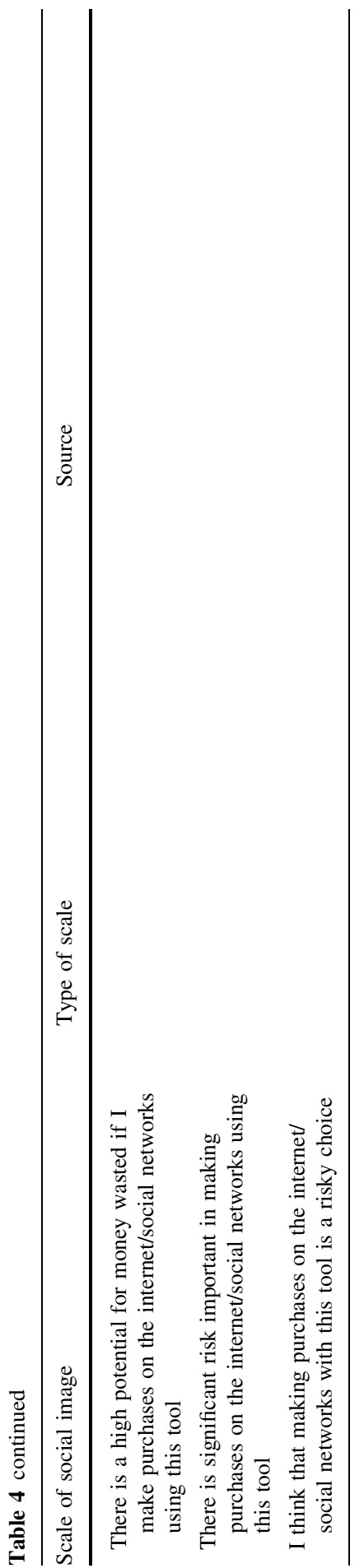




\section{References}

Agarwal, R., \& Karahanna, E. (2000). Time flies when you're having fun: Cognitive absorption and beliefs about information technology usage 1. MIS Quarterly, 24(4), 665-694.

Agarwal, R., Ahuja, M., Carter, P. E., \& Gans, M. (1998, December). Early and late adopters of IT innovations: Extensions to innovation diffusion theory. In Proceedings of the DIGIT conference (pp. $1-18)$.

Ajzen, I., \& Fishbein, M. (1980). Understanding attitudes and predicting social behavior. Londres: Prentice Hall International.

Anderson, J. C., \& Gerbing, D. W. (1988). Structural equation modeling in practice: A review and recommended two-step approach. Psychological Bulletin, 103(3), 411.

Antevenio (2010). Segundo estudio Antevenio Mobile sobre tendencias en navegación móvil. http:// blog.antevenio.com/2010/12/segundo-estudio-antevenio-mobile-de-tendencias-en-navegacion-movil/. Accessed 15 July 2013.

Bagozzi, R. P. (1994). Structural equation model in marketing research. Basic principles. Cambridge MA: Blackwell Publishers.

Bhattacherjee, A., \& Premkumar, G. (2004). Understanding changes in belief and attitude toward information technology usage: A theoretical model and longitudinal test. MIS Quarterly, 28(2), 229-254.

Buellingen, F., \& Woerter, M. (2004). Development perspectives, firm strategies and applications in mobile commerce. Journal of Business Research, 57(12), 1402-1408.

Chau, P. Y., \& Lai, V. S. (2003). An empirical investigation of the determinants of user acceptance of internet banking. Journal of Organizational Computing and Electronic Commerce, 13(2), 123-145.

Cheong, J. H., \& Park, M. C. (2005). Mobile internet acceptance in Korea. Internet Research, 15(2), $125-140$.

Chung, N., \& Kwon, S. J. (2009). The effects of customers' mobile experience and technical support on the intention to use mobile banking. Cyber Psychology \& Behavior, 12(5), 539-543.

Cotec Foundation (2011). Informe Cotec 2011.

Davis, F. D. (1989). Perceived usefulness, perceived ease of use, and user acceptance of information technology. MIS Quarterly, 13(3), 319-340.

Davis, F. D., Bagozzi, R. P., \& Warshaw, P. R. (1989). User acceptance of computer technology: A comparison of two theoretical models. Management Science, 35(8), 982-1003.

Dehning, B., \& Stratopoulos, T. (2003). Determinants of a sustainable competitive advantage due to an IT-enabled strategy. The Journal of Strategic Information Systems, 12(1), 7-28.

Del Barrio, S., \& Luque, T. (2012). Análisis de Ecuaciones Estructurales. In T. Luque (Ed.), Técnicas de Análisis de datos en investigación de mercados. Barcelona: Pirámide.

Fadil, F. B. (2009). User acceptance of MyKad as an e-commerce tool in Malaysia. Thesis, University Utara Malaysia.

Farrell, A. M., \& Rudd, J. M. (2009). Factor analysis and discriminant validity: A brief review of some practical issues. Melbourne: ANZMAC.

Fornell, C., \& Larcker, D. F. (1981). Evaluating structural equation models with unobservable variables and measurement error. Journal of Marketing Research, 18, 39-50.

Gefen, D., \& Straub, D. W. (2000). The relative importance of perceived ease of use in is adoption: A study of e-commerce adoption. Journal of the Association for Information Systems, 1(8), 1-28.

Gil-Pechuán, I., \& Conesa-García, M. P. (2013). The use of social technologies in Spanish young people: A global behaviour model in teenagers. Global Business Perspectives, 1-20.

Glajchen, D. (2011). Comparative analysis of mobile phone-based payment services in the United States and South Africa. Dissertation, Graduate Faculty of the School of Business and Technology Management in fulfillment of the requirements for the Degree of Doctor, Prescott Valley, AZ.

Glass, R., \& Li, S. (2010). Social influence and instant messaging adoption. Journal of Computer Information Systems, 51(2), 24-30.

Glover, S., \& Benbasat, I. (2011). A comprehensive model of perceived risk of e-commerce transactions. International Journal of Electronic Commerce, 15(2), 47-78.

Goffman, E. (1967). Interaction ritual. New York: Pantheon.

Gupta, B., Iyer, L. S., \& Weisskirch, R. S. (2010). Facilitating global e-commerce: a comparison of consumers' willingness to disclose personal information online in the US and in India. Journal of Electronic Commerce Research, 11(1), 41-52. 
Hair, J. F., Anderson, R. E., Tatham, R. L., \& William, C. B. (1995). Multivariate data analysis with readings. New Jersey: Prentice Hall, Inc.

He, F., \& Mykytyn, P. P. (2007). Decision factors for the adoption of an online payment system by customers. International Journal of E-Business Research (IJEBR), 3(4), 1-32.

Herrero, A. (2005). El proceso de adopción de nuevos sistemas de venta: Aplicación al comercio electrónico entre particulares y empresas. Thesis, University of Cantabria.

Herrero, A., Rodríguez, D. B., \& García de los Salmones, M. M. (2005). La propensión a innovar en la adopción del comercio electrónico B2C: un análisis sobre la base de la Teoría de Acción Razonada. XVII Encuentro de Profesores Universitarios de Marketing (pp. 723-738).

Hossain, L., \& de Silva, A. (2009). Exploring user acceptance of technology using social networks. The Journal of High Technology Management Research, 20(1), 1-18.

Hsu, M. H., Chuang, L. W., \& Chiu, S. P. (2011). The impact of trust formation, trust transference, and perceived risk in online group-buying context. International conference on opto-electronics engineering and information science (ICOEIS 2011), 24-25 Dec, Xi'an (pp. 2922-2927).

Hu, X., Li, W., \& Hu, Q. (2008, January). Are mobile payment and banking the killer apps for mobile commerce? In Proceedings of the 41st annual Hawaii international conference on system sciences (pp. 84-84). New York: IEEE.

Huang, Y. C., Tsay, W. D., Huang, C. H., Lin, Y. H., \& Lai, M. C. (2011, August). The influence factors of electronic bill presentment and payment-A case study of mobile phone bill. In $20112 n d$ International conference on artificial intelligence, management science and electronic commerce (AIMSEC) (pp. 4844-4847). New York: IEEE.

Innopay (2009). Mobile payments 2010. Market analysis and overview. http://www.innopay.com. Accessed 15 July 2013.

Interactive Advertising Bureau Spain y Elogia (2011). III Estudio sobre Redes Sociales en Internet. http:// www.iabspain.net. Accessed 15 July 2013.

Jarvenpaa, S. L., Tractinsky, N., \& Vitale, M. (2000). Consumer trust in an Internet store. Information Technology and Management, 1(1-2), 45-71.

Karahanna, E., Straub, D. W., \& Chervany, N. L. (1999). Information technology adoption across time: A cross-sectional comparison of pre-adoption and post-adoption beliefs. MIS Quarterly, 23, 183-213.

Kargin, B., \& Basoglu, N. (2006, June). Adoption factors of mobile services. In IEEE international conference on mobile business 2006, ICMB'06.

Kesharwani, A., \& Bisht, S. S. (2012). The impact of trust and perceived risk on internet banking adoption in India: An extension of technology acceptance model. International Journal of Bank Marketing, 30(4), 303-322.

Koufaris, M. (2002). Applying the technology acceptance model and flow theory to online consumer behavior. Information Systems Research, 13(2), 205-223.

Kuo, Y. F., \& Yen, S. N. (2009). Towards an understanding of the behavioral intention to use $3 \mathrm{G}$ mobile value added services. Computers in Human Behaviour, 25(1), 103-110.

Lafuente, R. (2005). Los Servicios Financieros Bancarios Electrónicos. Valencia: Tirant lo Blanch.

Lee, J. H., \& Song, C. H. (2013). Effects of trust and perceived risk on user acceptance of a new technology service. Social Behavior and Personality, 41(4), 587-597.

Liébana-Cabanillas, F. (2012). El papel de los sistemas de pago en los nuevos entornos electrónicos. Thesis, University of Granada.

Lorenzo Romero, C., Alarcón de Amo, M. D. C., \& Gómez Borja, M. Á. (2011). Adopción de redes sociales virtuales: ampliación del modelo de aceptación tecnológica integrando confianza y riesgo percibido. Cuadernos de Economía y Dirección de la Empresa, 14(3), 194-205.

Lu, J., Yao, J. E., \& Yu, C. S. (2005). Personal innovativeness, social influences and adoption of wireless Internet services via mobile technology. The Journal of Strategic Information Systems, 14(3), 245-268.

Lu, J., Liu, C., Yu, C. S., \& Wang, K. (2008). Determinants of accepting wireless mobile data services in China. Information \& Management, 45(1), 52-64.

Luo, X., Li, H., Zhang, J., \& Shim, J. P. (2010). Examining multi-dimensional trust and multi-faceted risk in initial acceptance of emerging technologies: An empirical study of mobile banking services. Decision Support Systems, 49(2), 222-234.

Malhotra, N. K. (1997). Investigación de Mercados. Un enfoque práctico (2 ${ }^{\mathrm{a}}$ ed.). México: Prentice Hall Hispanoamericana.

McKnight, D. H., Kacmar, C. J., \& Choudhury, V. (2004). Dispositional trust and distrust distinctions in predicting high-and low-risk internet expert advice site perceptions. E-Service Journal, 3(2), 35-55. 
Miyazaki, A. D., \& Fernandez, A. (2001). Consumer perceptions of privacy and security risks for online shopping. Journal of Consumer Affairs, 35(1), 27-44.

Moon, J. W., \& Kim, Y. G. (2001). Extending the TAM for a World-Wide-Web context. Information \& Management, 38(4), 217-230.

Moore, G. C., \& Benbasat, I. (1991). Development of an instrument to measure the perceptions of adopting an information technology innovation. Information Systems Research, 2(3), 192-222.

Multi-sector Business Association of Electronic, Information and Communications Technologies, Telecommunications and Digital Content Companies and Accenture (2011). Retos y oportunidades del universo digital móvil en España: más ubicuo, más social, más personal. http://www.accenture. com/es-es/Pages/insight-retos-oportunidades-universo-digital-movil.aspx. Accessed 15 July 2013.

Muñoz, F. (2008). La adopción de una innovación basada en la Web. Thesis, Universidad de Granada.

Muñoz-Leiva, F., Hernández-Méndez, J., \& Sánchez-Fernández, J. (2012). Generalising user behaviour in online travel sites through the Travel 2.0 website acceptance model. Online Information Review, 36(6), 879-902.

National Observatory of the Telecommunications and Information Society (2011). Annual report on digital content in Spain. http://www.ontsi.red.es. Accessed 15 July 2013.

National Observatory of the Telecommunications and Information Society (2012). Estudio sobre Comercio Electrónico B2C 2011. http://www.red.es/media/registrados/2011-11/1321000922018. pdf. Accessed 15 July 2013.

National Statistics Institute (2012). Survey on the equipment and use of information and communication technologies in households. http://www.ine.es. Accessed 15 July 2013.

Nunnally, J. C. (2010). Psychometric theory 3E. New York: Tata McGraw-Hill Education.

Pikkarainen, T., Pikkarainen, K., Karjaluoto, H., \& Pahnila, S. (2004). Consumer acceptance of online banking: An extension of the technology acceptance model. Internet Research, 14(3), 224-235.

San Martín Gutiérrez, S., \& López Catalán, B. (2010). Posibilidades de la compraventa B2C por teléfono móvil en comparación con Internet. Cuadernos de Gestión, 10(1), 17-34.

San Martín Gutiérrez, S., \& López Catalán, B. (2012). Determinantes personales de la satisfacción del comprador por teléfono móvil. XXII Encuentro de Profesores Universitarios de Marketing (p. 115).

Sánchez Franco, M. J., Rondán Cataluña, F. J., \& Villarejo Ramos, Á. F. (2007). Un modelo empírico de adaptación y uso de la Web. Utilidad, facilidad de uso y flujo percibidos. Cuadernos de Economía y Dirección de la Empresa, 10(30), 153-179.

Sanz-Blas, S., Ruiz-Mafé, C., Martí-Parreño, J., \& Hernández-Fernández, A. (2013). Assessing the influence of motivations and attitude on mobile social networking use. Global Business Perspectives, 1(2), 1-16.

Schierz, P. G., Schilke, O., \& Wirtz, B. W. (2010). Understanding consumer acceptance of mobile payment services: An empirical analysis. Electronic Commerce Research and Applications, 9(3), 209-216.

Shih, Y. Y., \& Fang, K. (2004). The use of a decomposed theory of planned behavior to study Internet banking in Taiwan. Internet Research, 14(3), 213-223.

Shin, D. H. (2007). User acceptance of mobile Internet: Implication for convergence technologies. Interacting with Computers, 19(4), 472-483.

Spanish Telecommunications Market Commission (2012). Informe Trimestral de la Comisión del Mercado de las Telecomunicaciones 2011. http://www.cmt.es. Accessed 15 July 2013.

Stanley, M. (2009). The mobile Internet report. www.morganstanley.com/institutional/techresearch/. Accessed 15 July 2013.

Swilley, E. (2010). Technology rejection: The case of the wallet phone. Journal of Consumer Marketing, 27(4), 304-312.

Tamayo, B. (1999). Nuevos campos para la innovación: Internet y el comercio electrónico de bienes y servicios. http://www.navactiva.com/es/descargas/pdf/atic/cotec.pdf. Accessed 15 July 2013.

Taylor, S., \& Todd, P. A. (1995). Understanding information technology usage: A test of competing models. Information Systems Research, 6(2), 144-176.

Teo, T. S., \& Liu, J. (2007). Consumer trust in e-commerce in the United States, Singapore and China. Omega, 35(1), 22-38.

Troshani, I., \& Rao Hill, S. (2008). A proposed framework for mobile services adoption: A review of existing theories, extensions, and future research directions. In G. C. Karmakar \& L. S. Dooley (Eds.), Mobile multimedia communications: Concepts, applications and challenges (pp. 85-108). Hershey, PA: Idea Group Publishing.

Venkatesh, V., \& Bala, H. (2008). Technology acceptance model 3 and a research agenda on interventions. Decision Sciences, 39(2), 273-315. 
Venkatesh, V., \& Davis, F. D. (2000). A theoretical extension of the technology acceptance model: Four longitudinal field studies. Management Science, 46(2), 186-204.

Venkatesh, V., Morris, M. G., Davis, G. B., \& Davis, F. D. (2003). User acceptance of information technology: Toward a unified view. MIS Quarterly, 27(3), 425-478.

Wakefield, R. L., \& Whitten, D. (2006). Mobile computing: A user study on hedonic/utilitarian mobile device usage. European Journal of Information Systems, 15(3), 292-300.

Weber, R. H., \& Darbellay, A. (2010). Legal issues in mobile banking. Journal of Banking Regulation, 11(2), 129-145.

Wei, G., Xinyan, Z., \& Yue, M. (2011, May). Literature review on consumer adoption behavior of mobile commerce services. In 2011 International conference on e-business and e-government (ICEE) (pp. 1-5). New York: IEEE.

Zhou, T. (2012). Examining location-based services usage from the perspectives of unified theory of acceptance and use of technology and privacy risk. Journal of Electronic Commerce Research, 13(2), 135-144. 